\title{
Nheengatu Language and Its Role in the Tactics of Construction of Indigenous Identity*
}

\author{
Maria Sílvia Cintra \\ Department of Linguistics and Modern Languages, Universidade Federal de São Carlos/UFSCAR, São Carlos, Brazil \\ Email: msilviam@ufscar.br
}

Speech communities and languages, independently of writing, do not define closed groups of people who understand one another but primarily determine relations between groups who do not understand one another. if there is language, it is fundamentally between those who do not speak the same tongue. Language is made for that, for translation, not for communication (Deleuze \& Guattari, 1987).

How to cite this paper: Cintra, M. S. (2018). Nheengatu Language and Its Role in the Tactics of Construction of Indigenous Identity. Advances in Anthropology, 8, 289-301.

https://doi.org/10.4236/aa.2018.84012

Received: July 29, 2018

Accepted: October 19, 2018

Published: October 22, 2018

Copyright $\odot 2018$ by author and Scientific Research Publishing Inc. This work is licensed under the Creative Commons Attribution International License (CC BY 4.0).

http://creativecommons.org/licenses/by/4.0/ (c) (i) Open Access

\begin{abstract}
Nheengatu is one of the co-official languages of São Gabriel da Cachoeira in the Amazon region (AM/Brazil). About 8000 people in the Upper Rio Negro region speak it, and there exists a contemporary movement for its revitalization in the state of Pará (PA/Brazil). Based upon field research in both these regions, this paper bears reflections on the inter-relations existing between language and identity including references in the areas of Applied Linguistics, Culture Semiotics and Anthropology. I propose a discussion on Nheengatu language, which is often considered in a dysphoric way, i.e., as if it had been imposed on the natives, resulting only from the colonizers' strategies. I propose we can instead envisage it from the perspective concerning the tactics constructed by the aboriginals in order to preserve and reconquer their identity, i.e., from the point of view of a Poetics of Relation within a complex, contradictory and hybrid linguistic approach.
\end{abstract}

\section{Keywords}

Identity, Translation, Nheengatu, Resistance

\footnotetext{
${ }^{\star}$ The reports and reflections I present imply the results of five-year field research supported by FAPESP (FAPESP 2009/13871-4 and 2012/ 15852-0). One of the actions involved the coordination of a scientific expedition to Upper Rio Negro (Amazon, Brazil) in 2010. Other issues are derivations of the preliminary project. They have led to the construction of didactic material aimed to give support to teachers because of law $11.645 / 08$. The first version of this article was published with the title "The role of nheengatu language in the construction of indigenous identity" (Revista Digital de Políticas Linguísticas-RDPL/AUGM-Associación de Universidades Grupo Montevideo). I counted on the essential contribution by Lillian DePaula (UFES) for the translation into English and final revision for this version. I also acknowledge TRADUSP and LETRA for supporting this publication.
} 


\section{Kua Resé1}

Aikué musapiri co-oficiais nheenga São Gabriel da Cachoeira tawa. Baniwa, Nheengatu, Tukano. Kwa Nheengatu, paá, uriku 8000 mirá ita upurungitá waá. Aikué, yuíri, Pará upé, amu mirasá upurungitá uputári nheengatu rupi. Anhembué wã mukui tendawa upé apinima apuderi arama. Kua muraki ramé amukamee waá identidade asuí nheenga umuatari yepeasu. Asendu-katu arã kua resé asikári wã Linguística Aplicada, Semiotica da Cultura asuí Antropologia ramé. Iké ambúri yamaité kuri amu nhengatu resewara duki sunde yasendu kuera. Supisawa suí kua nheenga. Kolonizadori ti umunhã aé. Kua nheenga uriku amu marandua. Indijina ita ugustári nheengatu ta supé arama uyumunhã kirimbawa. Kuarese ixé apurungitá kuri.

\section{Introduction}

In 2010, during the month of July, I developed ethnographic and participative field research in the Upper Rio Negro city of São Gabriel da Cachoeira, located in the Ethno educational Territory I, in the state of Amazon, in the North of Brazil. Considered the third largest municipality in Brazil by territorial area, the city's population in the urban area is around 15,000 . The entire region has 40,806 people according to 2008 IBGE census. They are mostly indigenous peoples in surrounding tribes and villages scattered over $109,185 \mathrm{~km}^{2}$.

My initial objectives were to verify:

1) In which ways the main guidelines for differentiated education, present in the National Curriculum Referential for Indigenous Education-RCNEI (Brasil, 1998), had been understood and reinterpreted/translated by the indigenous teachers;

2) In which ways issues related to literacy and to the didactic work concerning oral modality have been proposed in RCNEI and applied by teachers and educators;

3) How the acceptance (or non-acceptance) of differentiated education occurs in the Upper Rio Negro communities and how the values thus created imply tension/friction issues;

4) Which role Nheengatu represented among indigenous people as a co-official language.

To assign the survey a more participative and collaborative dimension, we offered the university extension course "Formation in Inclusive and Differentiated Education" (PROEX/UFSCar) with a 30-hour duration and designed for Elementary and High School Indigenous teachers, who worked in the urban center and in the communities. The course was based on the theoretical presuppositions I will be referring to in the next item. I aimed at verifying the research objectives above mentioned. In this paper, I present the results concerning the

${ }^{1}$ I present here the abstract in Nheengatu. The reader will also find the last paragraph of this paper with its translation into Nheengatu. I wanted thus to open the space for dialogue with a casual speaker of this language. Ribeiro (PPGL/UFSCar) made the translations into Nheengatu. 
fourth objective, which implies the functioning of Nheengatu language in the two regions where the research was developed ${ }^{2}$.

I call attention to the fact that occurrences happening in regions more commonly known as belonging to a certain geographical frontier bring us further understanding of other phenomena in which the characteristic said of frontier may have less visibility. Therefore, I use here the term "frontier" with a double meaning once the research to which I refer in fact happened in a region close to a geographical frontier encompassing Brazil, Venezuela, and Colombia. I also explore the meaning given to the term "frontier" in a semiotic sense (Lotman, 2005) to consider better the role of Nheengatu in other places that do not present a geographical localization proper to national frontier regions but represent a frontier role as well. In this sense, I use the word "frontier" in a style similar to that adopted by the Caribbean writer Edouard Glissant when referring to Créole (2009).

It is worth noting, from the off go, the data highlighted by the indigenous undergraduate Kezo (2014: p. 8), on the linguistic heterogeneity of the Brazilian territory: “(...) presently we have the information that there still exist the complexity of more than 200 peoples with more than 180 cataloged languages".

\section{The Semiosphere, the Frontier and the Translation Processes}

According to Russian semioticist Yuri Lotman (2005), a sum of bilingual filters represent the semiotic frontier: as it passes through the filters, a text (be it oral or written) is translated into another or into other languages. This fact does not necessarily mean the translation of one language into another considered foreign - as is the case for national languages like Portuguese, English, Spanish or German, for instance. From the perspective examined, translation happens at each instance, as an intrinsic mechanism for the functioning of any human language. Translation, thus, is a mechanism inherent in language, a necessary aspect for its functioning, for its existence. It implies a heuristic principle, which means that people, in general, are active and creative.

The semiosphere, as a semiotic macrospace, includes a group of interrelated semiotic microspaces, so that each one of such spaces participates in the dialogue and involves a dialogue space. According to Lotman (2005), there are no isolated monosemantic systems: their articulation is based on a heuristic necessity, since nothing taken in isolation may, in fact, be effective or meaningful. The semantic system only works, for that very reason, when immersed inside a specific semiotic continuum, filled with multivariant semiotic models placed in a sequence of hierarchic levels that call for translation as part of its ontology, so that the transitions between different systems and its levels may happen. It is impossible, therefore, to have a fluid or immediate transition: it must pass through the so-called bilingual filters, whose existence is based on the presupposition that the

${ }^{2}$ Research Project approved by the Ethic Commitee CAAE-0145.0.135.000-09. Detailed data of research have been presented in Martins (2011, 2013a, 2013b). 
passage happens inside a heterogeneous space. In that sense, the heterogeneity of the products, that is, the fact that heterogeneity and hybridity characterize the texts themselves comes from the hybrid ethos of the semiotic space in which they are processed, a phenomenon that characterizes the diverse (Glissant, 2009).

Relying on the existence of such phenomena, I take to consider the role Nheengatu language has played in Brazilian territory. As a general language or a lingua franca, it is the diachronic result of the unfolding of Tupi language, which, in its turn, was already used as lingua franca before the European colonizers arrived. We deal with a language characterized by translation and by frontier in an exceptional or extreme way, a language for speakers of a number of other languages, be it Tukano, Baniwa or even the Portuguese language. Such a fact assigns it, in a very sui generis way, the qualities of hybridity, plasticity and constant modification, i.e., a linguistic functioning similar to that of the Créole language described by Glissant.

The first phase of the field research developed in 2010 in the Upper Rio Negro region-nicknamed "Cabeça de Cachorro"/"Dog Head" thanks to its design in the northwest portion of the map of Brazil-helped me understand in loco the oral and written modalities of the various languages circulating there. Lotman refers to different languages distributed in different semiospheres, being each socio-historical and cultural sphere endowed with its own ethos, that is, a peculiar identity. I could indeed notice the functioning of such a phenomenon, i.e., of the linguistic diversity there present, once the county of São Gabriel da Cachoeira has the largest concentration of different ethnic groups (Wanano, Baré, Yanomami, Desana, Kubeo, Werekena, among others). I could also notice the sui generis hybrid functioning of the Portuguese language itself, as I had the opportunity to observe, for example, in its bureaucratic role in the Education Department for the city ${ }^{3}$.

As I have stressed elsewhere (Martins, 2015), there is a translation aspect proper to every language and it would be inadequate and idealistic viewing a fluid transition from one linguistic modality to another, without taking into consideration the socio-historical processual components inherent therein. Moreover, we cannot neglect the role cultural artifacts play amidst the processes of transition.

From 2013 on, I started to develop the second phase of the research. The goal at this point was to elaborate bilingual learning and teaching material. Our research subjects in this phase were the indigenous youngsters who at that time were moving from their communities (some of them located in the Upper Rio Negro region) into an academic environment. I understand, anyway, that the results thus obtained in the area of Applied Linguistics with specific subjects are extensive to other realities, especially within contemporary society marked by ${ }^{3}$ It is worthwhile noting that Portuguese is the official language of Brazil, which is a country with a continental dimension. São Gabriel da Cachoeira, on its turn, is one of the few cities in which other languages are considered with an official status. According to Kezo (2014), there are four indigenous co-official languages in Brazil, three in São Gabriel da Cachoeira/AM (Nheengatu, Baniwa and Tukano) and one in the county of Tacuru/MS (Guarani). 
migration and transitions happening within different territorialities ${ }^{4}$.

The core question, in this case, came to be the form in which identity and cultural artifacts interact, once we presuppose that cultural artifacts are mediating elements in the passage of bilingual filters from one to another semiosphere. According to Bartlett (2007), books and other learning material, as cultural artifacts, may provide the enhancing of literacy practices and skills, once they mobilize the quality of "feeling literate" on the part of the learner. In our case, there was the expectation that the bilingual books would fulfill such a role with indigenous and non-indigenous educators, for whom they were primarily aimed. I also stress, nevertheless, the role they have had in creating a literate identity for the indigenous writers themselves: whether in the case of the indigenous undergraduates at the Federal University of São Carlos, or involving indigenous educators whom I accompanied in Santarém (state of Para, Brazil), on whose experience I shall shortly report later in this paper ${ }^{5}$.

It is important emphasizing, however, the fact that, at least in part and in a paradoxical way, I deal with Nheengatu language as a cultural artifact: on one hand, because it was part of the books, which the teachers produced; on the other hand, because it may be considered, by itself, a cultural artifact. Nevertheless, it is important calling the attention to its role as a constitutive and heuristic part of the socio-historical subjects' identities as well. It is an inherent part of their identity and of their personhood as active and proactive subjects. Such artifacts-either the language itself or other instruments and utensils-play a translation role at each frontier.

It is interesting, for this very reason, to consider the existence of a continuum or tensional gradient bound by limit and border within and in between the semiospheres. This is a fact that will necessarily lead us to postulate, not only for heterogeneity and for hybridity, as for plasticity and deformations. Alongside, one must consider not only the continuum in the speech genres (i.e. in language), but also a semio-spatial-temporal continuum. In other words, a continuum of socio-historical discursive manifestations in which literacy and identity are aspects of complex translation phenomena, with contradictions, tensions, and pressure in addition to the presence of cultural artifacts as subjectifiers (Latour, 2005).

\section{Considerations on the Nheengatu Language}

In order to make clear the functioning of Nheengatu as a frontier language, I will

${ }^{4}$ The "Universidade Federal de São Carlos"/UFSCar has had, since 2008, a differentiated access program aimed to aboriginal students with a place reserved in each course in its four campuses. At this moment, in the year of 2018, indigenous representation at our university counts 29 different ethnicities, such as: Balatiponé, Xavante, Pankararu, Baniwa, Kanela, Atikum, Wassu Cocar, Baré, Cambeba, Terena, Manchinery, Guarani Mbya, Pankará, Pataxó, Ha Hã Hãe, Tupiniquim, Huni Kui, Piratapuia, Dessano, Tukano, Tariano, Rickbatsa, Xukuru.

${ }^{5}$ Ariabo Kezo, who belonged to the Umutina community (Mato Grosso) was still an undergraduate when he wrote two books: one designed to the teaching of Umutina language to eight-year-old children; the other involving a mythological narrative. Both books included illustration also designed by him. 
raise some provoking questions:

Is Nheengatu an artificial language, partially idealized by the colonizers and imposed by them upon the natives of the land of Pindorama (Tupi lexicon for "palm tree"), from the XVI century on? Or is it, instead, a general language, lingua franca adopted purposefully by the Aboriginals themselves so as to communicate and perform commercial interactions? Maybe, in fact, it has participated in both scenarios.

Is it a contemporary version of the ancient Tupi and, if that is the case, what is there in Nheengatu that already existed in the classic language? Would the relation between Nheengatu and Ancient Tupi be similar to that existing between Vulgar and Classic Latin, or even between the normative cult version of Portuguese language adopted in Brazil and its colloquial counterpart?

Is it a fact that the Nheengatu language, which was spoken nationally until the mid- $19^{\text {th }}$ century, only survives today, about a hundred and fifty years afterward, in the north region of Brazil, having been erased because of a national decree in other areas? Anyway, how does one explain that this could have happened: is that, after all, the way languages function and thrive, through government interventions?

Would there still be signs of the structure of Nheengatu in the Portuguese language, besides the eventual borrowing of vocabulary?

These and other questions still guide the horizons of the Research Group "Languages in Transition"/LEETRA (CNPq, hosted by the Language Department at UFSCar). One of our members, Professor Eduardo de Almeida Navarro, is a serious scholar of Tupi and author of dictionaries and grammar books on both Tupi and Nheengatu. Navarro (2012) affirms referring to Nheengatu, which he defines as a supra-ethnic language, once aboriginals pertaining to different groups as well non-aboriginals have spoken it:

Amazonian lingua franca was the one through which Northern riverside cabocla civilization has found its expression. It was defined from the moment indigenous people were inserted inside the white colonizer's world by means of slavery or miscegenation. Hundreds of different aboriginals have spoken it. Aboriginals from different languages and cultures knew it. It was by means of língua franca that indigenous America met Portuguese America. It represented an encounter between different worlds.

In other words, we may say that Nheengatu is a frontier language, that plays the friction role characteristic of the Poetics of Relation. Equipped with the interest of creating learning material-an interest that sprung, as I mentioned before, from the field research developed in the Upper Rio Negro during the first phase of research in 2010-it was, however, only more recently that I have begun to better comprehend the roles it plays in the Amazonian region. Considered a general language or lingua franca, it holds elements from the Ancient Tupi within a syntax relatively closer to the Portuguese language. Nevertheless, it is a fact that, according to Brazilian Kayapo writer and politician Kaka Werá Jecupé (1998), Tupi itself had the functioning of a hegemonic language of commerce 
when European colonizers arrived in the XVI century, so that it already held the title of a general language:

Around 3000 years ago there was a series of happenings that brought about a split. It was during that period that Tupy began to dominate. The Tupy people, great river navigators, hunters and farmers, were endowed with a dominating spirit (...) It is from this period on that Tupy language and culture expanded to many peoples north and south of the country (Jecupé, 1998: p. 45, my translation into English).

Contact with the Portuguese language, the language of the colonizers, i.e., of the people who came with the political and economic objective of dominating Brazilian territory from then on, also made it possible for new processes of hybridization and creolization, not unusual in the history of the evolution of people and of their languages. In other words, Nheengatu is not-nor could it be-a language imposed entirely by the colonizers-it implies, instead, a phenomenon happening in South America in a sui generis way, that was very different, for instance, from the imposition of vernacular Latin in the Iberian Peninsula. In order to reflect on the amplitude of such a phenomenon, I will bring Ilari's (2003) words which we can transpose to our discussion on the hegemonic role Tupi already played before the European colonizers arrived at the Brazilian territory, with the necessary reservation in what concerns the erasing aspects mentioned, which I rather understand as creolization aspects:

The history of the romance languages is a good example in this sense: the speeches that gained the status of national languages not only went through a process of transformation in koiné (characterized by erasing the more local forms), but also through a slow process of elaborating the necessary linguistic resources so as to attend the demands created by the growing dimensions of interests and by the cultural diversification.

My attention was drawn, all the same, towards the special form in which we found Nheengatu being spoken on the streets of São Gabriel da Cachoeira, side by side with co-official languages Tukano and Baniwa, and with the Portuguese language as well. I also could note that the Education Department for the city had chosen Nheengatu in order to accomplish the official obligation of teaching an indigenous language in the so-called differentiated indigenous education. Specially assigned teachers taught it regularly in Indigenous Learning Schools, with two hours of classes weekly, very much following the number of hours afforded in general in Brazil to the teaching of English as a foreign language. At that time, in July of 2010, with the assistance of the local Secretary Department, I could get in contact with the many different initiatives towards the production of didactic material in indigenous languages, especially in the three co-official Indigenous languages in this city. The "Pamaali" school is one of the most notable schools in the region, located in Baniwa territory, and it was in Baniwa language that I could examine a number of more sophisticated learning materials, 
leading me, at that moment, to believe that many people still spoke Baniwa in the Upper Rio Negro region.

Time passes, and in 2014, with the production of the trilingual learning material "Kabari Teepa" - in Nheengatu, Baniwa and Portuguese (Leetra Indigena, 15), I came to understand, through an undergraduate student belonging to the Baniwa community, that their language was hardly ever spoken in the region, and that his people had adopted Nheengatu as their first language. I received the same type of information from a Wanano student, saying that very few of his ethnic group still speak their language and that they had given preference either to Nheengatu or to Tukano. In a playful tone, one of them referred to these people, the ones who no longer spoke their ancestors' language (including himself), with the wanano term meaning "wasted" (this information was passed to me during an informal semi-structured field research in the region, in 2014). Only more recently, when we published the bilingual volume "Escola Kariamã conta umbuesâ" (Leetra Indígena 17), I got the information that Baniwa is still spoken in the Upper Içana River, near the frontier of Colombia ${ }^{6}$.

It was, however, in Santarém - in the state of Pará, also in the North of Brazil-that, in a special form, it became clearer how Nheengatu has been functioning as an instrument for self-identification by the population of ribeirinhos (riverside cabocla). This fact made it possible for me to think of Nheengatu through the perspective of the tactics constructed by different indigenous groups in resistance to the still ongoing process of colonization, i.e., from the perspective of a Poetics of Relation. Riverside caboclos have been using such tactics in order to deal with the different strategies of domination with which they have had to get along, especially since the arrival of the European colonizers on the Brazilian territory at the beginning of the XVI century. More recently, as a subterfuge for being recognized as indigenous people, i.e., as an instrument for resistance.

\section{The Production of Different Artifacts and the Transition to the Nheengatu Language in Santarém}

As mentioned above, it was during the first phase of field research in the Upper Rio Negro, eight years ago, that I realized the importance of the production of didactic material considering the law 11.645/08. The law claims in its Article 26-A: "It is now mandatory to have studies on Afro and Indigenous Brazilian culture and history in elementary and secondary public schools" (This information may be captured at http://www.planalto.gov.br/ccivil_03/_ato2007-2010/2008/lei/111645.htm).

I submitted a project to a sponsoring institution, which contemplated the demand. Since then, in the second phase of field research, I began to investigate the possibility of publishing didactic material as cultural artifacts that could better provide mediation in between the different semiospheres, within the concept given by Lotman (2005) to this term and taking into consideration the identity

${ }^{6}$ All the didactic material I mention here can be accessed at www.leetra.ufscar.br. 
component inherent in it. I developed the project together with undergraduate students, as also with representatives from different ethnic groups (a wanano, for example).

As part of this project, I visited, in 2014, the city of Santarem. I had been in contact with a Professor and Anthropologist from UFOPA (Universidade Federal do Oeste do Pará) who had been developing actions for the learning and teaching of Nheengatu to the riverside population, previously called caboclas and presently undergoing a process of self-identification as indigenous people.

In 2015, I also took part of courses for teacher training and for continuing education, this time directed towards the learning of the Nheengatu language on the part of indigenous teachers. This course was given to 45 teachers from different ethnic groups, like Arapium, Borary, Maytapu, Tupinambá, Cara Preta, Cumaruara, Tapajó, Tupaiú, Jaraki, Apiaká, and Juruna. The fact is that, just as the Baniwa and the Wanano, these educators had lost contact with the traditional language of their ethnicity, and took the Nheengatu language as their indigenous language for self-identification.

I learned together with them some elements of Nheengatu, and at a certain point during the course, it was suggested that the participants should elaborate a reading book to be used by the students. It was the starting point for the production of "Nheengatu Tapajoara" (Leetra Indígena 16). My contribution as editor was to highlight the importance-as is presently viewed in Applied Linguisticsthat different discourse genres be presented to provide elements that would favor the learning of Nheengatu language. The teachers collected and produced narrative stories, recipes, words to songs, mythical narratives, maps, charts, glossaries, as the stretch of text presented below, created and elaborated by the indigenous educators collectively, with respective translations within a proposal of bilingual material:

Kuá mbeumbeusawaitá usasá waá mukiriarisawaitá rupi, maã 200 akaiú nhúntu. Yané ariaitá upurai upurungitá yumimisáwa rupi, u upitá ikúntu. Ma, wií aintá upurungitá píri, umukatúru arã kuá manduarisáwa awá umaramunha suí. Sesewara, yandé yaviverir? wií yané iwí upé.

These stories were handed down each generation for almost 200 years. Our grandparents had to speak in secret or stay quiet. However, today they speak much more, to keep the memory of those that fought. Thanks to them, we still live on our lands. That is why even today we, Indigenous from the Tapajos and Arapiuns, fight for the demarcation of our lands and territories (Leetra Indígena 16).

I concluded that these subjects-once they not only used but had themselves created the material-could be literate and feel likewise by means of the appropriation of Nheengatu language ("to be and to feel literate", Bartlett, 2007). Moreover, following the ideas elaborated by Street (2007), and applying them to the reality I have been describing, they constituted themselves as indigenous subjects in their own personhood once involved in such practices. Paradoxically, perhaps, because they switched from their ethnical languages, i.e., the languages 
of their ancestors, in favor of a general language, the language of commerce. Humanly, however, because the language pertaining to the other, once appropriated, was transformed into a language of their own, since, also paradoxically, "All culture is originally colonial. (...) Every culture institutes itself through the unilateral imposition of some 'politics' of language" (...) (Derrida, 2001: p. 55).

At this point of my argument, I want to recall considerations proposed by Chernela (2013) concerning Wanano women and the way they explored, in their struggle for citizenship and recognition, apparently adverse situations located in the periphery for their conquering of freedom and agency:

The periphery, as Yuri Lotman maintained, is a site of dynamic creativity, where limitations that appear to be "natural", "given", or "fixed" are transcended and a new reality, a re-invention, is created. In this setting, members of the community reinvigorate their relations to one another. As a "least colonized space", the periphery constitutes a retreat from the colonized spaces in the center. Rather than any accumulation of recognizable individual wealth, what we find is a singular direction toward greater agency and greater freedom.

It is yet worthwhile highlighting the fact that, from the viewpoint of Language Studies and of Translation Studies, the presupposition is not true, that the presence of a language of commerce or lingua franca would forcibly lead to the erasure of local languages and dialects. Or even that teaching indigenous children the Portuguese language, for instance, necessarily implies a process of erasure of their native language, of their culture, of their identity. I understand it is an area open to further research and we can raise some hypotheses, work principles or instigating issues, such as: does learning a new language involve the erasure of another one or, on the contrary, it contributes to a better understanding of it, particularly because of the metalinguistic reflexive role it implies? Contemporary research has been pointing to this second hypothesis.

\section{Concluding Remarks}

It is a fine time to revisit the concept of semiosphere, the presupposition that we are always in regions of the frontier and under translation challenges as well. As Deleuze \& Guattari (1995) call our attention, languages are meant for translation, and not for communication.

To claim that Nheengatu is a frontier language, may not seem too enlightening at this point, since under Lotman's (2005) perception, as also Deleuze \& Guattari's (1995), the frontier self is part of the self of any language; a fact that, at every point, takes us to the processes of translation. Translation as reformulation and as a passage from one hierarchical level to another, a process that confirms, moreover, that there are no isolated languages, i.e., that languages are always located inside processes of communication and interrelation. A process that also confirms that the learning of a second or third language never occupies the space 
of a previous one, nor substitutes it.

Besides that, it is interesting to consider the semiosphere, the socio-historic topos, and the form in which, within this circumstance, i.e., this space-temporal milieu, identity processes are underway, once, as we have been viewing, the "caboclo" ethos may be converted into an indigenous ethos through the appropriation of a language. This fact does not only imply a mis-en-scène, a play of masks or a play of scenes. Self-identification brings to itself the territoriality and the citizens' demands for their rights to property, inside a conflict arena, particularly in this case. The presence of timber company owners and their repulsion to the fact that landless caboclos would conquer the necessary strength for contestation help us understand better such an arena and the power that the adherence to a language and an ancestrality (even when ambiguous or paradoxical) may propitiate.

The research data to which I have referred point to the conclusion that, in a situation of conflict and partial forgetting of the ancestral language, learning Nheengatu language, as a lingua franca, a language of commerce and contact between indigenous subjects, has contributed to reconquering indigenous identity. It is possible to presuppose that elements of the ancestral languages and cultures have been revived as well. Moreover, it is noteworthy that, as a lingua franca, Nheengatu tends to hybridize with local languages, manifesting different syntactic-semantic aspects in different regions in the process of appropriation by subjects pertaining to different ethnicities and speakers of different native languages: Baniwa, Tukano, Wanano, among others, in the case of Upper Rio Negro (AM); Arapium, Borary, Maytapu, Tupinambá, among others, in the case of Santarém (PA).

Therefore, on the one hand, I reckon it is undeniable that the preservation and revitalization of indigenous languages are of utmost importance for the maintenance of cultures and the penetration inside certain issues that may be lost forever. This may be the case for literary chants and narratives, like the mythic Baniwa narratives and sacred chants involving Kuwai, the son of Nhiaperikuli, which can only be known in all their literary formal complexity by means of the original Baniwa language. My most recent research on Rainforest Indigenous Literatures has brought the possible indication that Yurupary-an indigenous tradition recognized by UNESCO in 2010-can imply, in part, a derivation of the Kuwai narrative, which is much more complex in details and in spatial and historical relations. A tradition that is maintained by the few Baniwa indigenous people who still know their ancestor's language in more detail. Moreover, in the contemporary movement towards the recognition of indigenous chants and narratives as genuine literature, we cannot neglect the fact that the access to the texts in their original language is of fundamental importance in the description of literary formal traits.

On the other hand, however, as I have been affirming, it pertains to languages and to socio-historical subjects, in general, the inescapable phenomena of muta- 
tion, translation, and hybridity, particularly inside conflict areas. In this sense, if we, as researchers and intellectuals, should not underestimate the perverse aspects of the imposition of colonizers' languages in general, we also should not act as if we wanted to force unnaturally human and historical phenomena in what concerns certain transformations, which we cannot reduce to mere imposition. In any case, we are not before the substitution of languages, but, rather, before multilingualism. In addition, the maintenance of cultural wealth up to a certain point does not relate directly or logically to the maintenance of ancestral languages. It is in this sense, moreover, that as I have been showing the learning of an indigenous language that in principle did not relate to one's ancestrality may conduct to the recovering of ancient traditions by means not suspected beforehand.

By the way, it is worthwhile mentioning a much more profound and critical issue, which relates to the initiatic and sacred power of words. It is an issue closely related to shamanism inside a world in ruins, i.e., inside a sphere, a sacred semiosphere that claims for its preservation and alerts us to the imminence of the falling of sky (Albert \& Kopenawa, 2013). It is clear, however, that we face a danger that is much more comprehensive and transcends the mere preservation of isolated languages. Instead, it claims for a Poetics of Relation, which demands urgently the most different and unforeseen means for connection, in the sense of the creation of networks that may help sustain the sky preventing it from falling together with all of its components.

In order to conclude this paper, I want to make the provocative statement: a language never occupies the space of another language; it adds to the former one (s), exactly because that space, inside which it enters, from the beginning and forever is a space of translation.

Translating into Nheengatu, we would read:

Pausapé, ambúri yepé maã yamaité arama: ti aikué yepé tetama ntu upé yepé nheenga. Tiramé yepé nheenga ntu yepé tetama supé. Nheenga ramé muíri amu nheenga ita uiku. Yepe tetama uriku muiri nheenga nhaãsé yepé nheenga uiku amu nheenga kuara upe. Panhe kuri tetama nheenga itá umuyereu arama.

\section{Conflicts of Interest}

The authors declare no conflicts of interest regarding the publication of this paper.

\section{References}

Albert, B., \& Kopenawa, D. (2013). The Falling of Sky. Words of a Yanomami Shaman. Cambridge: Harvard University Press.

Bartlett, L. (2007). To Seem and to Feel: Situated Identities and Literacy Practices. Teachers College Record. Columbia University, 51-69.

Brasil, M. da E. (1998). Referencial Curricular Nacional para as Escolas Indígenas. Brasília: MEC/SEF [Curricular Referential for Aboriginal Schools].

Chernela, J. (2013). Direções da Existência: O trabalho de mulheres indígenas como 
domésticas na Paris dos Trópicos. In: M. S. C. Martins (Ed.), Ensaios em Interculturalidade: Literatura, Cultura e Direitos de Indígenas em época de globalização. Campinas: Mercado de Letras [Essays on Interculturality: Aboriginal Literature, Culture and Rights in a Time of Globalization].

Deleuze, G., \& Guattari, F. (1995). Mil Platôs-Capitalismo e Esquizofrenia. Rio de Janeiro: Ed. 34. [A Thousand Plateaus].

Glissant, E. (2009). Philosophie de la Relation. Paris: Gallimard.

Ilari, R. (2003). Linguagem-Atividade Constitutiva (Ideias e Leituras de um Aprendiz). Revista Letras, No. 61, Especial, 45-76. Curitiba: Editora UFPR [Language-A Constitutive Activity].

Jecupé, K. W. (1998). A terra dos mil povos. São Paulo: Peirópolis [The Land of the Thousand Peoples].

Kezo, L. A. (2014). Revendo a historiografia do Brasil. LEETRA Indígena. Número 8, Volume 1. São Carlos/SP: Universidade Federal de São Carlos. Laboratório de Linguagens LEETRA. www.leetra.ufscar.br

Latour, B. (2005). Reassembling the Social: An Introduction to Actor-Network-Theory. New York: Oxford University Press.

Leetra Indigena. São Carlos/SP: Universidade Federal de São Carlos. Laboratório de Linguagens LEETRA. http://www.leetra.ufscar.br/cakephp/pages/view_biblioteca

Lotman, J. (2005). On the Semiosphere. Sign Systems Studies. 33.1.

Martins, M., \& Sílvia, C. (2011). Os temas geradores e a educação escolar indígena diferenciada à luz dos conceitos de cronotopo, de etnicidade e de semiosfera [Generating Themes and Indigenous School Education in the Light of the Concepts of Chronotopos, Ethnicity and Semiosphere]. São Paulo: Humanitas.

Martins, M., \& Sílvia, C. (2013a). Literacy, Ethnicity and Style. Advances in Anthropology, 3, 7-12. http://www.scirp.org/journal/AA/

Martins, M., \& Sílvia, C. (2013b). Ensaios em Interculturalidade: Literatura, Cultura e Direitos de Indígenas em época de globalização [Essays on Interculturality: Aboriginal Literature, Culture and Rights in a Time of Globalization]. Campinas: Mercado de Letras.

Martins, M., \& Sílvia, C. (2015). O papel da língua nheengatu na construção da identidade indigena [The Role of Nheengatu Language in the Construction of Indigenous Identity]. Montevidéo: Universidad Nacional de Córdoba (UNC).

Navarro, E. (2012). O último refúgio da língua geral no Brasil [The Last Refuge of the Franca Língua in Brasil]. Estudos Avançados, 26. https://doi.org/10.1590/S0103-40142012000300024

Street, B. (2007). Perspectivas interculturais sobre o letramento [Intercultural Perspectives on Literacy]. Revista de Filologia e Linguística Portuguesa, 7, 16-22. 